\title{
Hubungan Caring Perawat Terhadap Loyalitas Pasien di Rumah Sakit
}

\author{
Nur Afifah ${ }^{1 *}$, Sri Yulia ${ }^{1}$, Muliyadi $^{2}$
}

1Program Studi Ilmu Keperawatan Sekolah Tinggi Ilmu Kesehatan Muhammadiyah Palembang, Palembang, 30262, Sumatera Selatan, Indonesia.

2Departemen Keperawatan, Politeknik Kesehatan Kementerian Kesehatan Palembang, Palembang, 30151, Sumatera Selatan, Indonesia.

*Korespodensi: nur.afifah2212@gmail.com

\begin{abstract}
Abstrak: Loyalitas pasien dapat mempengaruhi perkembangan rumah sakit sehingga perlu dilakukan pengendalian faktor, salah satunya meningkatkan kualitas pelayanan keperawatan melalui pendekatan caring. Tujuan penelitian ini adalah untuk mengidentifikasi caring perawat di Rumah Sakit XX Palembang. Metode penelitian kuantitatif dengan desain deskriptif korelatif dan pendekatan cross sectional. Pengambilan data dengan accidental sampling sebanyak 38 responden. Alat pengumpulan data menggunakan kuesioner sebanyak 25 item pernyataan caring perawat dan 18 item pernyataan loyalitas pasien. Analisis data menggunakan uji chi square. Hasil penelitian adalah caring perawat baik 30 responden (78,9\%), Aspek kontrak baik 23 responden (60,5\%), aspek etika baik 28 responden $(73,3 \%)$, aspek spiritual baik 24 responden $(63,2 \%)$ dan loyalitas yang baik 24 responden $(63,2 \%)$. Hasil penelitian menunjukan bahwa ada hubungan caring perawat dengan loyalitas ( $p$ value $=0,034$ ), ada hubungan aspek kontrak dengan loyalitas ( $p$ value $=0,006)$, ada hubungan aspek etika dengan loyalitas ( $p$ value $=$ $0,021)$ ada hubungan aspek spiritual dengan loyalitas $(p$ value $=0,035)$. Kesimpulan dan saran adalah ada hubungan caring perawat dengan loyalitas pasien. Perlu dilakukan upaya meningkatkan caring perawat yaitu membuat pedoman tentang caring perawat.
\end{abstract}

Kata Kunci : Caring, Perawat, Loyalitas Pasien.

Abstract: Patient loyalty can affect hospital development, so it is necessary to control the influencing factors, one of them is by improving the quality of nursing services through a caring approach. The purpose of this study was to identify nurse's caring at Palembang XX Hospital. Quantitative research methods with a correlative descriptive design and cross sectional approach was used in this research. The sampling technique was accidental sampling with 38 respondents. Data collection tools using questionnaires as many as 25 items caring nurse statements and 18 items of patient loyalty statements. Data analysis used the chi square test. The results of the research are caring nurses good 30 respondents $(78.9 \%)$, contractual aspects are good 23 respondents $(60.5 \%)$, ethical aspects are good 28 respondents (73.3\%), spiritual aspects are good 24 respondents (63.2\%) and good loyalty 24 respondents $(63.2 \%)$. Research results show that there is a nurse caring relationship with loyalty ( $p$ value $=0.034)$, there is a relationship between contractual aspects and loyalty $(p$ value $=0.006)$, there is a relationship between ethical aspects and loyalty ( $p$ value $=0.021)$ there is a relationship between spiritual aspects and loyalty $(p$ value $=$ 0.035). The conclusion and suggestion is that there is a nurse caring relationship with patient loyalty. Efforts need to be made to improve caring nurses by making guidelines on caring nurses.

Keywords: Caring, Nurse, Patient Loyalty. 


\section{PENDAHULUAN}

Pelayanan kesehatan adalah organisasi yang diadakan secara bersamaan untuk menjaga dan meningkatkan kesehatan, mencegah dan menyembuhkan dan memulihkan kesehatan individu, keluarga, kelompok atau masyarakat (UU No 36, 2009). Salah satu komponen dari pelayanan kesehatan masyarakat adalah pelayanan keperawatan (UU No 36, 2009). Pelayanan keperawatan adalah suatu pelayanan yang kompeten yang merupakan bagian dari pelayanan kesehatan yang ditujukan kepada individu, keluarga, kelompok yang sehat maupun sakit. (UU No 38, 2014). Kualitas pelayanan keperawatan sebagai sesuatu keunggulan yang diharapkan dan pengendalian untuk memenuhi kebutuhan fisik dan psikologis pasien (Damayanti, 2013).

Kualitas pelayanan keperawatan sangat penting dalam meningkatkan kepuasan pasien (Suherni, 2014). Kaitan antara kepuasaan pasien dengan loyalitas (kesetiaan) tidak bersifat proporsional karena pasien yang merasa tidak puas/cukup puas cenderung akan menjauhi rumah sakit namun pasien yang merasakan puas cenderung menunjukkan sikap loyalitas terhadap rumah sakit untuk digunakan dimasa yang akan datang saat mereka mengalami penurunan kesehatan (Kotler, 2009). Loyalitas mempunyai lima dimensi yang terpenting yaitu kepercayaan (trust), komitmen psikologi (psychological commitment), perubahan biaya (switching cost), perilaku publisitas (word of mouth), dan kerjasama (cooperation) (Bologlu, 2002). Caring perawat ini dapat menjadi landasan utama dalam keperawatan untuk membangun interaksi antara perawat dan pasien yang berespon baik (Rahman, 2013). Caring secara umum bisa disebut sebagai suatu keahlian untuk berdedikasi bagi orang lain, pengawasan dengan waspada, menampakkan perhatian, perasaan empati pada orang lain dan perasaan cinta atau menyayangi yang merupakan keinginan keperawatan (Perry, 2014).

Tiga aspek penting yang mendasari keharusan perawat untuk care terhadap orang lain adalah aspek kontrak, aspek etika, aspek spiritual (Burnard, 2009). Penelitian ini bertujuan untuk mengetahui hubungan caring perawat dengan loyalitas pasien sehingga dapat meningkatkan tingkat pemanfaatan rumah sakit oleh masyarakat (pasien).

\section{METODE}

Jenis penelitian ini adalah kuantitatif dengan desain deskriptif korelatif dan pendekatan cross sectional. Populasi pada penelitian ini yaitu jumlah rata-rata pasien di Rumah Sakit XX adalah 2641 orang. Teknik pengambilan data dengan accidental sampling sebanyak 38 responden di Rumah Sakit XX. Penelitian ini dilaksanakan diseluruh Ruang Rawat Inap Rumah Sakit XX. Alat pengumpulan data menggunakan kuesioner sebanyak 25 macam pernyataan caring perawat dan 18 macam pernyataan loyalitas pasien. Penelitian ini memakai uji chi square dengan derajat kepercayaan $95 \%(\alpha 0,05)$.

\section{HASIL}

Tabel 1. Distribusi Frekuensi Caring Perawat

\begin{tabular}{ccc}
\hline Caring & Frekuensi & Persentase (\%) \\
Perawat & & 78,9 \\
\hline Baik & 30 & 21,1 \\
Kurang & 8 & $\mathbf{1 0 0 , 0}$ \\
\hline Jumlah & $\mathbf{3 8}$ & \\
\hline
\end{tabular}


Hasil analisa univariat distribusi frekuensi Caring Perawat didapatkan mayoritas responden mengatakan Caring perawat baik yaitu 30 responden (78,9\%).

Tabel 2. Distribusi Frekuensi Caring Perawat Berdasarkan Aspek Kontrak

\begin{tabular}{ccc}
\hline Aspek Kontrak & Frekuensi & Persentase (\%) \\
\hline Baik & 23 & 60,5 \\
Kurang & 15 & 39,5 \\
\hline Jumlah & $\mathbf{3 8}$ & $\mathbf{1 0 0 , 0}$ \\
\hline
\end{tabular}

Hasil analisa univariat distribusi frekuensi aspek kontrak didapatkan sebagian besar mengatakan kontrak perawat baik yaitu 23 responden $(60,5 \%)$.

Tabel 3. Distribusi Frekuensi Caring Perawat Berdasarkan Aspek Etika

\begin{tabular}{ccc}
\hline Aspek Etika & Frekuensi & Persentase (\%) \\
\hline Baik & 28 & 73,7 \\
Kurang & 10 & 26,3 \\
\hline Jumlah & $\mathbf{3 8}$ & $\mathbf{1 0 0 , 0}$ \\
\hline
\end{tabular}

Hasil analisa univariat distribusi frekuensi aspek etika didapatkan mayoritas responden mengatakan etika perawat baik yaitu 28 responden $(73,7 \%)$.

Tabel 4. Distribusi Frekuensi Caring Perawat Berdasarkan Aspek Spiritual

\begin{tabular}{ccc}
\hline Aspek Spiritual & Frekuensi & Persentase (\%) \\
\hline Baik & 24 & 63,2 \\
Kurang & 14 & 36,8 \\
\hline Jumlah & $\mathbf{3 8}$ & $\mathbf{1 0 0 , 0}$ \\
\hline
\end{tabular}

Hasil analisa univariat distribusi frekuensi aspek spiritual didapatkan sebagian besar mengatakan spiritual perawat baik yaitu 24 responden $(63,2 \%)$

Tabel 5 Distribusi Frekuensi Loyalitas Pasien

\begin{tabular}{ccc}
\hline Loyalitas & Frekuensi & Persentase (\%) \\
\hline Loyal & 24 & 63,2 \\
Kurang & 14 & 36,8 \\
\hline Jumlah & $\mathbf{3 8}$ & $\mathbf{1 0 0 , 0}$ \\
\hline
\end{tabular}

Hasil analisa univariat distribusi frekuensi loyalitas pasien didapatkan sebagian besar responden mengatakan spiritual perawat baik yaitu 24 responden $(63,2 \%)$. 
Analisa Bivariat

Tabel 6. Distribusi Hubungan Caring Perawat terhadap Loyalitas Pasien

\begin{tabular}{cccccc}
\hline Caring & \multicolumn{2}{c}{ Loyalitas } & \multirow{2}{*}{ Total } & P value & OR \\
\cline { 2 - 3 } Perawat & Baik & Kurang & & & \\
\hline \multirow{2}{*}{ Baik } & 22 & 8 & 30 & & \\
& $73,3 \%$ & $36,7 \%$ & $100 \%$ & 0,034 & 0,25 \\
\multirow{2}{*}{ Kurang } & 3 & 6 & 8 & & \\
& $25 \%$ & $75 \%$ & $100 \%$ & & \\
\multirow{2}{*}{ Jumlah } & $\mathbf{2 4}$ & $\mathbf{1 4}$ & $\mathbf{3 8}$ & & \\
& $\mathbf{6 3 , 2} \%$ & $\mathbf{3 6 , 8} \%$ & $\mathbf{1 0 0} \%$ & &
\end{tabular}

Berdasarkan analisis hubungan caring Perawat terhadap loyalitas pasien didapatkan sebanyak 30 responden (100\%) yang mempersepsikan caring yang baik, 22 responden (73,3\%) didapatkan nilai $p$ $($ Value $)=0,034$ sehingga dapat disimpulkan ada hubungan yang signifikan antara caring perawat terhadap loyalitas pasien. Hasil analisis diperoleh nilai $O R=8,250$

Tabel 7. Distribusi Hubungan Aspek Kontrak terhadap Loyalitas Pasien

\begin{tabular}{cccccc}
\hline \multirow{2}{*}{ Aspek } & \multicolumn{2}{c}{ Loyalitas } & \multirow{2}{*}{ Total } & P value & OR \\
\cline { 2 - 3 } Kontrak & Baik & Kurang & & & \\
\hline \multirow{2}{*}{ Baik } & 19 & 4 & 23 & & \\
& $82,6 \%$ & $17,4 \%$ & $100 \%$ & 0,006 & 9,5 \\
\multirow{2}{*}{ Kurang } & 5 & 10 & 15 & & \\
& $33,3 \%$ & $66,7 \%$ & $100 \%$ & & \\
\multirow{2}{*}{ Jumlah } & $\mathbf{2 4}$ & $\mathbf{1 4}$ & $\mathbf{3 8}$ & & \\
& $\mathbf{6 3 , 2} \%$ & $\mathbf{3 6 , 8} \%$ & $\mathbf{1 0 0} \%$ & &
\end{tabular}

Berdasarkan analisis hubungan aspek kontrak terhadap loyalitas pasien didapatkan sebanyak 23 responden $(100 \%)$ jumlah total responden yang mempunyai aspek kontrak yang baik 19 responden $(82,6 \%)$ memiliki loyalitas yang baik terhadap rumah sakit, didapatkan nilai $p$-value $=0,006$ sehingga dapat disimpulkan ada hubungan yang signifikan antara aspek kontrak terhadap loyalitas pasien. Hasil analisis diperoleh nilai $O R=9,5$

Tabel 8 Distribusi Hubungan Aspek Etika terhadap Loyalitas Pasien

\begin{tabular}{|c|c|c|c|c|c|}
\hline \multirow{2}{*}{ Aspek Etika } & \multicolumn{2}{|c|}{ Loyalitas } & \multirow{2}{*}{ Total } & \multirow{2}{*}{ P value } & \multirow{2}{*}{ OR } \\
\hline & Baik & Kurang & & & \\
\hline \multirow{2}{*}{ Baik } & 21 & 7 & 28 & \multirow{4}{*}{0,021} & \multirow{4}{*}{7} \\
\hline & $75,0 \%$ & $25,0 \%$ & $100 \%$ & & \\
\hline \multirow{2}{*}{ Kurang } & 3 & 7 & 10 & & \\
\hline & $30,3 \%$ & $70,0 \%$ & $100 \%$ & & \\
\hline \multirow{2}{*}{ Jumlah } & 24 & 14 & 38 & & \\
\hline & $63,2 \%$ & $36,8 \%$ & $100 \%$ & & \\
\hline
\end{tabular}


Berdasarkan analisis hubungan aspek kontrak terhadap loyalitas pasien didapatkan sebanyak 28 responden $(100 \%)$ jumlah total responden yang mempunyai aspek etika yang baik 21 responden $(75,0 \%)$ memiliki loyalitas yang baik terhadap rumah sakit, didapatkan nilai $p$ (Value) $=0,021$ sehingga dapat disimpulkan ada hubungan yang antara aspek etika terhadap loyalitas pasien. Hasil analisis diperoleh nilai $O R=7$

Tabel 9. Distribusi Hubungan Aspek Spiritual terhadap Loyalitas Pasien

\begin{tabular}{cccccc}
\hline \multirow{2}{*}{$\begin{array}{c}\text { Aspek } \\
\text { Spiritual }\end{array}$} & \multicolumn{2}{c}{ Loyalitas } & Total & P value & OR \\
\cline { 2 - 3 } & Baik & Kurang & & & \\
\multirow{2}{*}{ Baik } & 19 & 6 & 25 & & \\
& $76,0 \%$ & $24,0 \%$ & $100 \%$ & 0,035 & 5,067 \\
\multirow{2}{*}{ Kurang } & 5 & 8 & 13 & & \\
& $38,5 \%$ & $61,5 \%$ & $100 \%$ & \\
\multirow{2}{*}{ Jumlah } & $\mathbf{2 4}$ & $\mathbf{1 4}$ & $\mathbf{3 8}$ & & \\
& $\mathbf{6 3 , 2} \%$ & $\mathbf{3 6 , 8} \%$ & $\mathbf{1 0 0} \%$ & &
\end{tabular}

Berdasarkan analisis hubungan aspek spiritual terhadap loyalitas pasien didapatkan sebanyak 25 responden $(100 \%)$ jumlah total responden yang mempunyai aspek kontrak yang baik 19 responden $(76,0 \%)$ memiliki loyalitas yang baik terhadap rumah sakit. didapatkan nilai $p$ (Value) $=0,035$ sehingga bisa diambil kesimpulan adanya hubungan yang antara aspek spiritual terhadap loyalitas pasien. hasil analisis diperoleh nilai $O R=5,067$

\section{PEMBAHASAN}

\section{Hubungan Caring Perawat terhadap Loyalitas Pasien}

Caring sebagai bentuk dasar dari praktik keperawatan dimana perawat membantu klien pulih dari sakitnya, memberikan penjelasan tentang penyakitnya, dan mengelola atau membangun kembali hubungan (Boykin dalam Perry, 2014). Pentingnya perilaku caring perawat memiliki beberapa manfaat untuk memperbaiki image perawat, meningkatkan mutu asuhan keperawatan dan pelayanan kesehatan salah satunya yaitu loyalitas pasien (Priyoto, 2015). Loyalitas adalah pembentukan sikap dan pola perilaku seorang konsumen terhadap pembelian dan penggunaan produk merupakan hasil dari pengalaman mereka sebelumnya (Griffin, 2013).

Penelitian ini selaras jika dibandingkan dengan Penelitian yang sudah dijalani oleh Wijaya (2014) yang mendapatkan 58 pasien $(80,6 \%$ ) yang mempersepsikan bahwa caring perawat baik dan memiliki tingkat loyalitas yang baik terhadap rumah sakit. Caring perawat dapat meningkatkan mutu pelayanan dan memberikan dampak yang baik untuk rumah sakit, sehingga perlu dilakukan peningkatan caring perawat dengan cara melakukan beberapa pelatihan yang terkait caring perawat seperti : pelatihan komunikasi, pelatihan personality, mentoring keagamaan, membina hubungan saling percaya, empati, dan selalu bersikap ramah agar pasien nyaman.

\section{Hubungan Aspek Kontrak terhadap Loyalitas Pasien}

Aspek kontrak sendiri diartikan sebagai care yang diberikan sesuai dengan keinginan pasien, sebagai perawat yang profesional mempunyai kewajiban untuk memenuhi kontrak yang telah dibuat (Siswoyo \& Supriyanto, 2013). Keuntungan kesetiaan dapat disebut bersifat jangka panjang dan 
kumulatif, dimana meningkatnya kesetiaan pasien dapat menyebabkan profitabilitas yang lebih baik, retensi pegawai yang lebih tinggi, dan pondasi keuangan yang lebih stabil (Supriadi, 2011).

Penelitian Wijaya (2014) mengatakan hal ini yang ditandai dengan perawat yang berhasil dan membina hubungan saling percaya dengan pasien, sehingga kehadiran perawat dapat diterima oleh pasien dan membantu pasien merasa nyaman untuk mengungkapkan perasaannya kepada perawat, membina hubungan saling percaya, dan berkomunikasi.

Aspek kontrak ini memiliki peran penting dalam membina ikatan saling percaya dengan pasien, walaupun masih banyak aspek lain yang mempengaruhi tingkat loyalitas pasien. Hal ini ditegaskan bahwa menanggapi dengan rasa hormat dapat dilakukan perawat dengan membina ikatan saling percaya dan saling menolong serta meningkatkan dan menerima pengekspresian perasaan baik maupun buruk pasien (Supriyanto \& Ernawaty, 2010).

\section{Hubungan Aspek Etika terhadap Loyalitas Pasien}

Perilaku caring (aspek etika), yaitu ada beberapa cara dalam pendekatan dalam isu etika salah satunya yaitu pendekatan utilitarianisme yaitu sebuah pendekatan yang pertama kali diartikulasikan oleh Jeremy Bentham. Utilitarisme seringkali disampaikan dengan slogan, atau sesuatu yang hampir serupa dengannya, bahwa "sesuatu yang baik adalah sesuatu yang menyebabkan kebahagiaan terbesar bagi orang terbanyak". Tampaknya beralasan untuk memperdebatkan bahwa caring tidak mungkin menyebabkan perluasan ketidakbahagiaan dan oleh karena itu caring dapat dijustifikasikan sebagai tindakan yang "baik". Perspektif yang lebih positif menyatakan bahwa caring akan menghasilkan perluasan kebahagiaan secara tepat (Burnard, 2009).

Indikator kesetiaan yaitu melakukan transaksi secara teratur, Membeli produk selain dari produk atau jasa yang biasa dikonsumsi, Mengajak pada pihak lain, dan Menunjukkan penolakan atau daya tolak terhadap produk pesaing (Griffin, 2013). Pasien yang loyal terhadap rumah sakit disebabkan karena perawat yang mempunyai etika dan moral yang baik (Wijaya, 2014). Aspek etika ini memiliki peran penting dalam interaksi perawat dengan pasien menggunakan etika dan tata krama yang baik, walaupun masih banyak aspek lain yang mempengaruhi tingkat loyalitas pasien.

\section{Hubungan Aspek Spiritual terhadap Loyalitas Pasien}

Perawat yang "religius" adalah orang yang peduli, bukan karena dia sebagai perawat melainkan lebih karena dia merupakan satu agama atau kepercayaan. Sebagian besar agama mempunyai perilaku yang biasanya tertulis dalam kitab suci yang merekomendasikan untuk care kepada orang lain (Burnard, 2009). Setiap manusia mempunyai tiga keinginan yang bersifat spiritual yang mirip, yaitu keinginan akan arti dan tujuan hidup, keinginan untuk mencintai dan berhubungan, serta keinginan untuk mendapatkan pengampunan (Hamid, 2009). Manfaat perusahaan yang dapat menjaga pasien akan memperoleh banyak manfaat seperti: Menurunkan biaya pemasaran, Mempersingkat waktu dan biaya transaksi, Menurunkan biaya turn over, Meningkatkan cross selling, Word of mouth positif, menurunkan biaya kegagalan, seperti biaya ganti rugi Selain itu (Griffin dalam Sangadji, 2013). Aspek spiritual ini memiliki peran penting dalam interaksi perawat dengan pasien untuk mengingatkan bahwa hanya pertolongan Allah SWT yang dapat menyembuhkan penyakit, dokter dan perawat hanyalah perantara dari Allah SWT untuk membantu menyembuhkan penyakit, walaupun masih banyak aspek lain yang mempengaruhi tingkat loyalitas pasien. 


\section{KESIMPULAN}

Hasil penelitian ini didapatkan bahwa Ada hubungan antara caring perawat terhadap loyalitas pasien di Rumah Sakit XX Palembang tahun 2017 nilai $p$ (Value) $=0,034$. Ada hubungan antara aspek kontrak terhadap loyalitas pasien di Rumah Sakit XX Palembang tahun 2017 nilai $p$ (Value) $=0,006$. Ada hubungan antara aspek etika terhadap loyalitas pasien di Rumah Sakit XX Palembang tahun 2017 nilai $p($ Value $)=0,021$. Ada hubungan antara aspek spiritual terhadap loyalitas pasien di Rumah Sakit XX Palembang tahun 2017 nilai $p$ (Value) $=0,035$.

Saran penelitian ini pihak rumah sakit membuat pedoman dasar tentang caring perawat, pelatihan kepada perawat untuk pembentukan karakter atau personality, mentoring keagamaan, pelatihan mengenai perilaku caring perawat dalam aspek kontrak, aspek etika, serta aspek spiritual sehingga pihak rumah sakit mampu menjadi fasilitator perkembangan pelayanan dalam hal memberikan caring kepada pasien, hendaknya pihak rumah sakit memiliki evaluasi loyalitas dan melakukan evaluasi kepuasan pasien secara rutin untuk meningkatkan mutu pelayanan serta memiliki standar evaluasi caring dan memasukkan ke dalam evaluasi kinerja perawat.

Bagi institusi pendidikan pada mata kuliah yang membahas tentang caring perawat mahasiswa melakukan role play, melakukan kegiatan-kegiatan pengembangan aktivitas kampus dengan metode peningkatan soft skills caring di dalam kampus. Memberikan penanaman etika dan ilmu keagamaan sejak dini kepada mahasiswa serta memberikan bahasan tentang kode etik keperawatan secara terperinci dan jelas dengan menggunakan metode role model sehingga mahasiswa mampu menumbuhkan sikap caring terhadap pasien

Bagi peneliti selanjutnya diharapkan dapat menggunakan variabel yang lebih bervariasi dan mencakup penelitian yang lebih luas, sehingga penelitian tentang caring perawat dapat terus berkembang, dan kepada mahasiswa yang nantinya juga akan melakukan penelitian ini diharapkan dapat meneruskan dan menyempurnakan penelitian ini dengan variabel menghubungkan beberapa variabel yang tidak diteliti dalam penelitian ini, seperti: menghubungkan karakteristik responden dengan caring perawat dengan loyalitas pasien, menghubungkan caring perawat dengan kepuasan dan loyalitas pasien, menggunakan metode kualitatif tentang caring perawat.

\section{DAFTAR PUSTAKA}

Bologlu. (2002). Dimension of customer loyalty. Journal Cornell University, 43. 47- 59. January

2017. http://journals.sagepub.com/doi/pdf/10.11 77/0010880402431005

Burnard, P., \& Morrisson,P. (2009). Caring \& Communicating (2nd ed), (Dwi Widyawati \& Eny Meiliya, Penerjemah). Jakarta: EGC

Damayanti. (2013). Buku Pintar Perawat Profesional Teori dan Praktik Asuhan Keperawatan. Yogyakarta: Mantra Books

Griffin. (2013). Customer Loyalty: Menumbuhkan dan Mempertahankan Kesetiaan Pelanggan (Dwi Kartini Yahya, Penerjemah). Jakarta: Erlangga.

Hamid, A.Y.S. (2009). Bunga Rampai Asuhan Keperawatan Kesehatan Jiwa. Jakarta: EGC

Kotler., \& Philip. (2009). Manajemen pemasaran (12nd ed), (Benyamin Molan, Penerjemah). Jakarta: PT Mancanan Jaya Cemerlang

Perry. (2014). Fundamental Of Nursing: Fundamental Keperawatan (7nd ed). Jakarta: Salemba Medika

Rahman, dkk. (2013). Hubungan Persepsi Perilaku Caring Perawat dengan Loyalitas Pasien Rawat Inap Kelas III Rumah Sakit Paru Jember. Artikel Ilmiah Penelitian Mahasiswa Universitas Jember. December 22, 2017 http://repository.unej.ac.id/bitstream/hand le/123456789/60713/Melinda\%20Rahma n.pdf?sequence $=1$ 
Republik Indonesia. (2009). UU No 36 tentang kesehatan tahun 2009. January 13,2017 http://sireka.pom.go.id/requirement/UU- 36-2009-Kesehatan.pdf

Republik Indonesia. (2014). UU keperawatan no 38 tahun 2014 . January 13,2017 https://www.kemenkopmk.go.id/sites/default/files/produkhukum/ UU20Nomor3820Tahun202014.pdf

Sangadji M,. \& Sophia. (2013). Perilaku Konsumen. Yogyakarta: Penerbit Andi

Siswoyo, B.E \& Supriyanto, S. (2013). Strategi Switching Barriers untuk Loyalitas Pasien Rawat Inap Rumah Sakit Muhammadiyah Surabaya. Jurnal Administrasi Kesehatan Indonesia. 1. 1. May 15, 2017 http://journal.unair.ac.id/filerPDF/9.pdf

Supriyadi,. \& Setiawan. (2011). Loyalitas Pelanggan Jasa. Bogor: PT Penerbit IPB Press

Supriyanto,S \& Ernawaty. (2010). Pemasaran Industri Jasa Kesehatan. Yogyakarta: Andi Offset

Suherni. (2014). Hubungan kualitas pelayanan prima perawat dengan loyalitas pasien di RSUD dr. Pirngadi Medan. Tesis Magister Ilmu Keperawatan Universitas Sumatera Utara. December 24, 2016. http://repository.usu.ac.id/bitstream/12345 6789/44480/7.pdf

Wijaya, D. (2014). Model Strategi Switching Barriers Untuk Loyalitas Pasien Berbasis Perilaku Caring Perawat.
9. 72-85. December
15, 2016 http://jks.fikes.unsoed.ac.id/index.php/jks/a rticle/view 